\title{
Toxicity study and anti-trypanosomal activities of aqueous and methanol whole plant extracts of Brillantaisia owariensis on Trypanosoma brucei-induced infection in $\mathrm{BALB} / \mathrm{c}$ mice
}

Nafisa Garba Ayawa', Suleiman Babatunde Ramon-Yusuf², Yunusa Adamu Wada ${ }^{1 *}$ (D), Sonnie Joshua Oniye ${ }^{1}$ and Dalhatu Mukhtari Shehu'

\begin{abstract}
Background: The problem of drug resistance and toxicity in trypanosomiasis is ever-increasing, thereby creating a need to search for efficacious and safer alternatives that are of plant origin. We designed the present study to assess the oral acute toxicity, and anti-trypanosomal activity of Brillantaisia owariensis in mice.

Methods: Fifty-eight BALB/c mice were used for this study. For toxicity assessment, eighteen mice were divided into two groups of nine mice each, and acute single oral administration of the aqueous and methanol whole plant extracts of B. owariensis was assessed for each group as per Lorke's method. Mice were observed for signs of toxicity of liver and kidney organs after two weeks of oral administration. For the anti-trypanosomal activity, forty mice were divided into eight groups of five mice. Mouse in each group was inoculated with $0.1 \mathrm{~mL}$ containing $10^{6}$ T. brucei $/ \mathrm{mL}$. Following patency of 3 days, mice were treated at different dosages of methanol and aqueous extracts. Pre-infection, post-infection, and post-treatment data for rectal temperature, body weight, parasiteamia level, packed cell volume, and daily survival were monitored.
\end{abstract}

Results: The acute oral toxicity studies $\left(\mathrm{LD}_{50}\right)$ for methanol and aqueous plant extracts in this study were calculated as $3535 \mathrm{mg} / \mathrm{kg} / \mathrm{body}$ weight, and are non-toxic. No obvious histopathologic observation in the liver and kidney tissues. The mean daily rectal temperature and mean weights of all the treated mice were restored to normal values and significant $(\mathrm{P}, 0.05)$ in comparison to the positive control.

Parasitaemia clearance by both extracts was suppressive. The mean PCV values were significantly increased following treatment, and there was prolonged survival especially in mice treated with methanol extracts.

(Continued on next page)

\footnotetext{
* Correspondence: yunuwad@yahoo.com

${ }^{1}$ Department of Zoology, Faculty of Life Sciences, Ahmadu Bello University,

Zaria, Kaduna, Nigeria

Full list of author information is available at the end of the article
}

\section{Springer Open}

(c) The Author(s). 2021 Open Access This article is licensed under a Creative Commons Attribution 4.0 International License, which permits use, sharing, adaptation, distribution and reproduction in any medium or format, as long as you give appropriate credit to the original author(s) and the source, provide a link to the Creative Commons licence, and indicate if changes were made. The images or other third party material in this article are included in the article's Creative Commons licence, unless indicated otherwise in a credit line to the material. If material is not included in the article's Creative Commons licence and your intended use is not permitted by statutory regulation or exceeds the permitted use, you will need to obtain permission directly from the copyright holder. To view a copy of this licence, visit http://creativecommons.org/licenses/by/4.0/. 
(Continued from previous page)

Conclusion: The study concludes that the extracts of B. owariensis are relatively non-toxic with a good safety margin when administered to mice orally. Crude methanol extract exhibited better suppressive and haematinic antitrypanosomal activities than the aqueous extract, and it has a promising effect by its ability to reduce anaemia in mice challenged with T. brucei brucei, and prolonged survival.

Keywords: Trypanosomosis, Brillantaisia owariensis, Toxicity, Liver and kidney, Antitrypanosomal activity, Trypanosoma brucei, Aqueous and methanol extracts

\section{Introduction}

Trypanosomiasis is a neglected tropical infectious disease of medical and veterinary importance in sub-Sahara Africa caused by a protozoan parasite of the genus Trypanosoma. The species T. brucei brucei is responsible for African Animal Trypanosomiasis (AAT) called Nagana in West Africa, while T. $b$. rhodesiense and T. $b$. gambiense cause Human African Trypanosomiasis (HAT) or sleeping sickness [1, 2]. It is a parasitic disease that occurs in sub-Saharan Africa, within the distributional limits of its vector, the tsetse fly [3]. Control of trypanosomiasis is principally achieved by chemoprophylactic or chemotherapeutic agents [4]. Most of these drugs for the control of both animals and humans are chemically related [5]. It has been estimated that as many as 35 million doses of trypanocides are used annually in sub-Saharan Africa alone [6]. This represents a figure suitable to treat only around one-third of the cattle at risk [7]. The chemotherapy of African trypanosomiasis is limited by problems of scarcity of drugs, drug resistance, high price, adverse reaction and toxicity $[8,9]$. Therefore, it is important to search for cheaper, more effective, easily available, and less toxic chemotherapeutic agents for the treatment of the disease.

Majority of people from Africa, including Nigeria depend on medicinal plants for the treatment of various diseases, and most of these plants have proven to be effective but lack scientific elucidation. Indeed, there have been a lot efforts to discover new anti-trypanosomals typically of plant origin based on the available information of their use in folklore medicine [10]. Several studies have demonstrated the trypanocidal activity of various plants such as Tapinanthus globiferus, Peristrophe bicalyculata, Securidaca longipedunculata, Moringa oleifera, Garcinia hombroniana, Camellia sinensis, Salvia offiicinalis, Azadirachta indica, Morinda lucida, and Tridax procumbens $[4,11-17]$. However, the toxicity of herbal remedies, their adverse effects on integrity of internal organs such as the liver and kidney are mostly unknown. There has been claim that natural plant products are safe, these could be accepted only after the plant product have passed through toxicity testing using modern scientific methods.

Brillantaisia owariensis P. Beauv belongs to the family Acanthaceae, and it is a tropical African species widespread in the forest regions of western (Togo, Nigeria) and central Africa, westward to Guinea and Sierra Leone, eastward to South Sudan, and southward to northern Angola. B. owariensis commonly known as bush cow food is a perennial shrubby plant $20 \mathrm{~cm}-2 \mathrm{~m}$ tall [18]. Leaves of $B$. owariensis are used for the treatment of anemia by traditional healers in Congo [19]. The species is used to aid conception and is decocted to ease childbirth and menstrual pains. It is also used against stomach ache, chest conditions, infantile spleen affections, malnutrition, yaws, and rheumatism [18]. To the best of our knowledge, no available data on toxicity and trypanocidal activity of Brillantaisia owariensis in-vivo. Therefore, this study was designed to assess the oral acute toxicity, and anti-trypanosomal activity of Brillantaisia owariensis in $\mathrm{BALB} / \mathrm{c}$ mice.

\section{Materials and methods}

\section{Plant collection and authentication and processing}

The whole plant was collected from the wild in Ondo State, South western, Nigeria. After which it was identified in the Herbarium Unit, Department of Botany, Ahmadu Bello University Zaria. The whole plant was rinsed in running tap water severally, air-dried in the Laboratory and thereafter pulverised using mortar and pestle, and ground to a fine powder with an electric blender to enhance the penetration of the extracting solvents into the cells, thus facilitating the release of active principles [20].

\section{Plant extraction and concentration Maceration (cold water extraction) method}

Thirty grams $(30 \mathrm{~g})$ of the powdered whole plant was measured using a weighing balance and poured into a two-liter container, $1.5 \mathrm{l}$ of distilled water was gently added to it, tightly screw-capped, and agitated thoroughly. After two hours, the container was shaken thoroughly again and repeated thereafter at four hours interval. After $24 \mathrm{~h}$, the container was shaken thoroughly and the content was filtered gently using a sieve into a clean container. The filtrate was poured into an evaporating dish, placed on a water bath to obtain a solid and more concentrated form of the extract.

\section{Hot continuous extraction (Soxhlet) method}

About thirty grams ( $30 \mathrm{~g})$ of the powdered whole plant was measured into a sac-like mesh cloth. The sac was 
then placed into a flask containing $300 \mathrm{~mL}$ of methanol and mounted on a Soxhlet machine. A tube-like glass was fixed on the open end of the flask on the machine and covered, switched on, and set at $100^{\circ} \mathrm{C}$. As the solvent in the flask boils, it evaporates and soaks the content of the flask which gradually releases the chemical content leaving residues in the sac. This process continues until the content of the sac became white while the solvent appeared green. Thereafter, the machine was switched off, allowed to cool, the set up dismantled and the sac was removed. The extract was then collected in a bottle, transferred to an evaporating dish, placed in a water bath set at $100^{\circ} \mathrm{C}$ to allow the methanol to evaporate and a concentrated extract was obtained.

\section{Acute toxicity studies}

Acute oral toxicity of the whole plant extracts of $B$. owariensis was carried out using Lorke's [21] method, which involves two phases:

\section{Phase 1}

Nine mice were divided into three groups of three each. Each group of mice was administered different doses $(10,100$, and $1000 \mathrm{mg} / \mathrm{Kg})$ of the test substance. The mice were placed under observation for $24 \mathrm{~h}$ to monitor their behavior as well as mortality [21].

\section{Phase 2}

Three mice were distributed into three groups of one mouse each. Each mouse was administered higher doses of 1600,2500 , and $5000 \mathrm{mg} / \mathrm{kg}$, respectively, of the test substance and then observed for $24 \mathrm{~h}$ for behavior as well as mortality [21]. The $\mathrm{LD}_{50}$ was then computed as the geometric mean of the highest dose that did not cause mortality in mice and the lowest dose that caused mortality in the mice by the formula:

$$
\begin{aligned}
& \mathrm{LD}_{50}=\sqrt{\left(D_{0} \times D_{100}\right)} \\
& \mathrm{D}_{0}=\text { Highest dose that gave no mortality, } \\
& \mathrm{D}_{100}=\text { Lowest dose that produced mortality. }
\end{aligned}
$$

\section{Experimental design, trypanosome inoculation and treatment}

Forty adult BALB/c mice (Mus musculus) of both sexes weighing 19-22 $\mathrm{g}$ bred within the animal house, Faculty of Pharmaceutical Sciences, Ahmadu Bello University, Zaria were used. They were kept to acclimatize under standard laboratory conditions in the Department of Zoology, Zoology Research Laboratory, for 2 weeks before commencement of the experiment. They were housed in clean cages with wood shavings as bedding, which was changed twice a week. They were fed with animal feed (grower) and given access to clean water ad libitum. They were grouped into eight and each group has five mice. Mice from groups 1, 2, 3,4 , and 5 were infected intraperitoneally with $0.1 \mathrm{ml}$ of the inoculum containing about $1 \times 10^{6}$ trypanosomes $/ \mathrm{mL}$. Trypanosoma brucei brucei was obtained from stabilates maintained at the Department of Veterinary Parasitology and Entomology, A.B.U. Zaria, Nigeria. Treatment began on the day the parasites were first detected in the bloodstream which was three (3) days post-inoculation.

Group 1: Negative control; infected and treated with $1 \mathrm{ml}$ normal saline.

Group 2: Positive control; infected and treated with Diminazene aceturate $3.5 \mathrm{mg} / \mathrm{kg}$.

Group 3: Infected treated with aqueous extract (A-50 mg/kg/day).

Group 4: Infected treated with methanol extract (M-50 mg/kg/day).

Group 5: Infected treated with aqueous extract (A-75 mg/kg/day).

Group 6: Infected treated with methanol extract (M-75 mg/kg/day).

Group 7: Infected treated with aqueous extract (A-100 $\mathrm{mg} / \mathrm{kg} /$ day).

Group 8: Infected treated with methanol extract (M-100 mg/kg/day).

\section{Pharmacological evaluation of extracts \\ Determination of mean daily rectal temperature}

To obtain rectal temperature, each mouse was handrestrained and placed on a horizontal surface, e.g., a cage lid. The tail was then lifted, and a probe (covered with Vaseline) was gently inserted into the rectum to a fixed depth (typically, up to $2 \mathrm{~cm}$ ) [22].

\section{Daily weight changes}

The weights of the mice were monitored daily using an automated electronic scale. To weigh a mouse, a round plastic container was placed on the scale and adjusted to zero followings which the animal was dropped inside the container and subsequently weighed [23].

\section{Determination of Parasitaemia in experimental mice}

Parasitaemia level was monitored daily in blood obtained from the tail of infected mice. The number of parasites per $\mathrm{ml}$ of blood was determined microscopically at $\times 400$ magnification using the "rapid matching" method by Herbert and Lumsden [24], and the number of trypanosomes per field was converted to antilog to provide the absolute number of trypanosomes per $\mathrm{ml}$ of blood [25].

\section{Determination of packed cell volume}

A heparinized capillary tube was filled with blood obtained from the ocular vein to up to about three quarter; one side of the capillary tube was filled with modeling clay (plasticine). The filled tube was placed in the 
microhaematocrit centrifuge and spin at $12000 \mathrm{~g}$ for 5 min. The spinner tube was then placed into a specially designed scale, read and expressed as a percentage [26].

\section{Histopathologic examination of liver and kidney tissues}

After two weeks of single acute oral administration of the aqueous and methanol whole plant extracts of B. owariensis mice were sacrificed for histopathologic assessment of liver and kidney tissues. Tissue specimens collected from the kidney and liver were preserved in 10\% buffered neutral formalin (BNF). After $48 \mathrm{~h}$ of fixation, the tissue samples were processed (washed in 50\% and 70\% alcohol), embedded in paraffin wax and sectioned at $5 \mu \mathrm{m}$ using a microtome. The sections were mounted on clean greasefree glass slides and stained with Haematoxylin and Eosin (H\&E) stains. Histopathologic lesions were examined microscopically at X40 objective and photomicrography was done with the aid of a digital camera (Canon 16 Mpx). Grading of liver and kidney histological alterations were classified as mild, moderate and severe damage based on the level and severity of necrosis and lesions present.

\section{Data analysis}

The data obtained from the study were summarized; the mean rectal temperatures, mean weights changes, parasitaemia scores, mean packed cell volume, of all the animals in the groups were represented and compared on multiple line graphs using Microsoft Excel Chart Wizard [27].

\section{Results}

\section{Acute toxicity test}

\section{The median lethal dose $\left(L D_{50}\right)$ of crude methanol extract}

All animals administered with 10, 100, and $1000 \mathrm{mg} / \mathrm{kg}$ of crude methanol extract of $B$. owariensis did not show any signs of toxicity, their behavioural response was normal with no mortality recorded. In the second phase when 1600,2500 , and $5000 \mathrm{mg} / \mathrm{Kg}$ of the extracts were administered, tremor was observed in mice that received $2500 \mathrm{mg} / \mathrm{kg}$ and $5000 \mathrm{mg} / \mathrm{Kg}$, while changes in skin and fur were observed in the mice that received 2500 and $5000 \mathrm{mg} / \mathrm{Kg}$. Death was recorded in animals administered $5000 \mathrm{mg} / \mathrm{Kg}$ of the extract.

The $\mathrm{LD}_{50}$ was then computed as the geometric mean of the highest dose that did not cause mortality in mice and lowest dose that caused mortality in the mice.

$$
\begin{aligned}
& \mathrm{LD}_{50}=\sqrt{2500 \times 5000} \\
& \mathrm{LD}_{50}=3535.5 \\
& \approx 3536 \mathrm{mg} / \mathrm{kg} .
\end{aligned}
$$

The median lethal dose $\left(L D_{50}\right)$ of crude aqueous extract Animals administered 10 and $1000 \mathrm{mg} / \mathrm{Kg}$ showed rough fur as well as low food intake, death was recorded in mice administered $2500 \mathrm{mg} / \mathrm{kg}$ of the extract. The $\mathrm{LD}_{50}$ was then computed as:

$$
\begin{aligned}
& \mathrm{LD} 50=\sqrt{5000 \times 2500} \\
& \mathrm{LD}_{50}=3535.5 \\
& \approx 3536 \mathrm{mg} / \mathrm{kg} .
\end{aligned}
$$

\section{Acute toxicity of extract on histology of the liver and kidney}

Histopathological assessment of the sections of the liver administered aqueous and methanol extracts of $B$. owariensis at oral doses of 10 revealed mild alveoli congestion and lymphocyte hyperplasia in all the treatment group. The liver shows mild to moderate degrees of hepatic necrosis, lymphocyte hyperplasia with vascular congestion (Fig. 1 Plate I a-f). The histology of the kidney tissues also revealed Mild to moderate degrees of tubular adhesion, lymphocyte hyperplasia and tubular necrosis at lower ad higher dosages (Fig. 2 Plate II a-f).

\section{Pharmacological observation Rectal temperature}

Pyrexia was observed to occur during the post-infection periods but as the treatment began at day 3 post -infection, rectal temperature fluctuated within the normal range in comparison to the positive control. However, there was increase in rectal temperature above the normal for those mice in the negative control group (Fig. 3).

\section{Mean weight changes}

The weight of the mice were constant in all groups throughout the study period. There were no significant changes in the mean weights of mice throughout the experimental period (Fig. 4).

\section{Mean daily Parasitemia}

The pattern of parasitemia is represented in Fig. 5. Parasitaemia occurred in all the infected groups, 3 days post-inoculation. The parasites disappeared in the blood of mice treated with diminazene aceturate $(3.5 \mathrm{mg} / \mathrm{kg})$ $24 \mathrm{~h}$ after dose administration, while those treated with either the aqueous or methanol plant extracts remained parasitaemic throughout the experiment with some observed level of suppression (Fig. 5).

\section{Packed cell volume}

The mean baseline values of packed cell volumes of experimental mice prior to infection were $57.06 \pm 2.22$, $52.59 \pm 2.0,53.28 \pm 0.51,52.07 \pm 2.9,54.91 \pm 2.15,51.21 \pm$ $1.5,54.66 \pm 0.73$, and $52.5 \pm 1.71$ for treatments M100, M75, M50, A100, A75, A50, Positive contorl, and negative control, respectively (Fig. 6). These values decreased following 3 days post infection to $43.56 \pm 2.1$, $40.32 \pm 3.1$, 


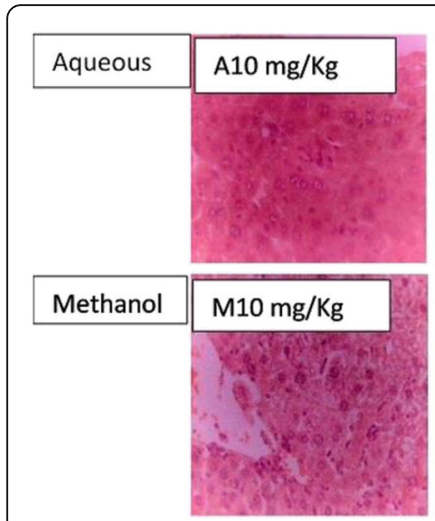

A

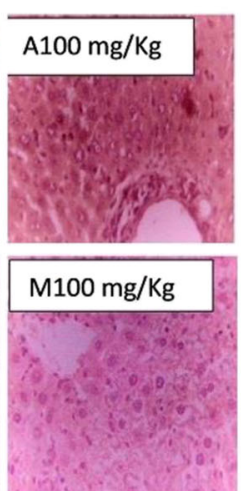

B

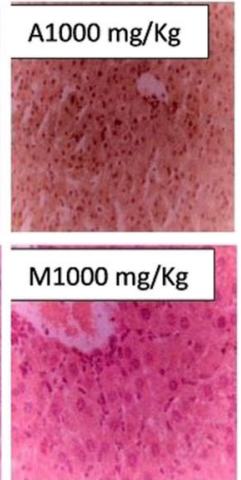

C

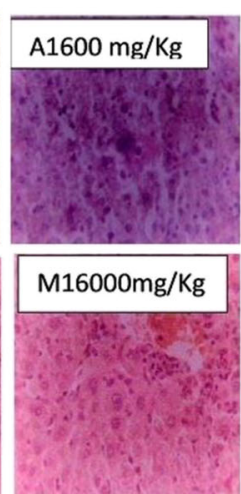

D

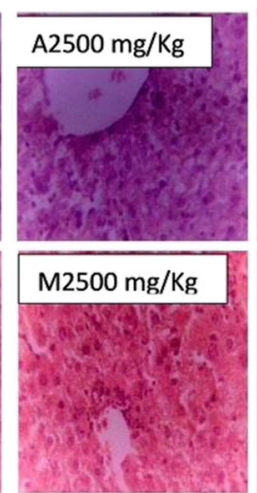

E

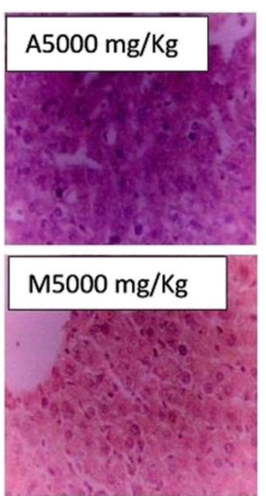

F

Fig. 1 Plate 1(a-f): Toxicity of aqueous and methanol whole plant extracts of Brillantaisia owariensis on the histology of Liver organ in BALB/C mice at lower and higher dosages. a Moderate hepatic necrosis at doses of A10 mg/Kg/body weights of aqueous and methanol extracts. $\mathbf{b}$ Mild vascular congestion at $100 \mathrm{mg} / \mathrm{Kg}$ aqueous extract, and moderate hepatic necrosis in mice orally administered $100 \mathrm{mg} / \mathrm{Kg} / \mathrm{body}$ weight of the methanol extracts. c Mild vascular congestion and lymphocyte hyperplasia in mice administered $1000 \mathrm{mg} / \mathrm{kg}$ aqueous and methanol extract. d Vascular congestion and slight hepatic necrosis and lymphocyte hyperplasia at $1600 \mathrm{mg} / \mathrm{kg}$ aqueous and methanol extract e Lymphocyte hyperplasia at $2500 \mathrm{mg} / \mathrm{Kg} /$ body weight of both aqueous and methanol extract. $\mathbf{f}$ Mild vascular congestion and moderate hepatic necrosis at $5000 \mathrm{mg} / \mathrm{Kg} /$ body weight of aqueous and methanol extracts. ( $\mathrm{H}$ and $\mathrm{E}, \mathrm{X} 400$ )

$42.34 \pm 2.12,43.45 \pm 0.96,42.11 \pm 3.01,39.31 \pm 2.22,40.56 \pm$ 1.83 , and $39.65 \pm 2.30$ for treatments M100, M75, M50, A100, A75, A50, Positive contorl, and negative control, respectively. However, following traetments with the methanol and aqueous B. owariensis whole plant extracts, the PCV values increased to $53.43 \pm 2.7,51.32 \pm 2.0,47.20 \pm 1.8$, $47.43 \pm 2.1, \quad 48.5 \pm .78,48.32 \pm 1.90$, and $52.10 \pm 2.3$, for treatments M100, M75, M50, A100, A75, A50, and Positive contorl, respectively (Fig. 6). Only the negative control (non treated) had a further decrease in the mean PCV value of $27.27 \pm 1.11 \%$ (Fig. 6).

Figure 8 represents the percentage increase in PCV values 22.66, 27.28, 11.48, 9.16, 15.17, 22.92, and 28.21\% for animal treated with M100, M75, M50, A100, A75, A50, and Positive contorl, respectively (Fig. 7). Only the negative non treated control had a percentage decreaes in PCV value $31.22 \%$ following post infection and treatment. There was significant increase in the PCV values

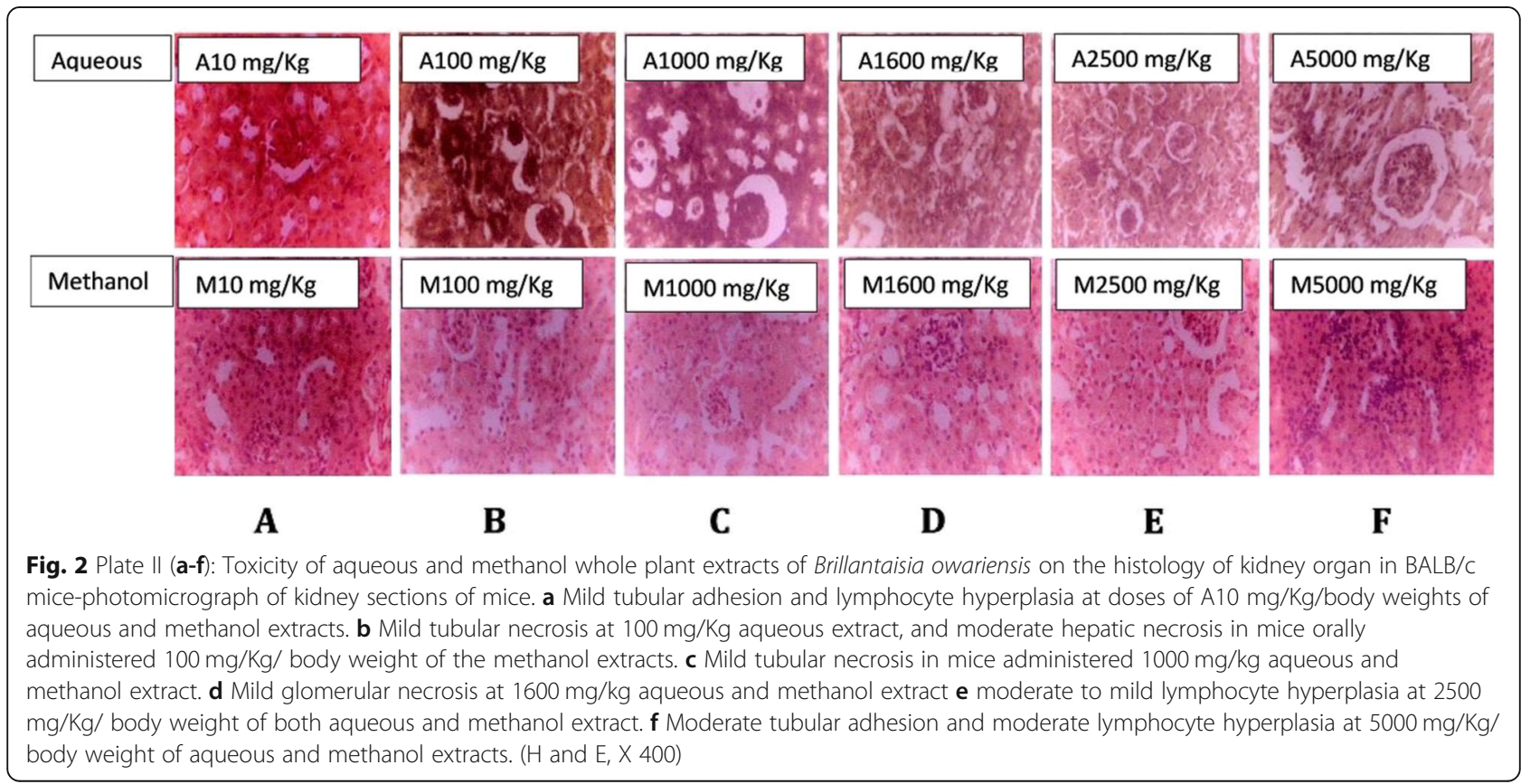



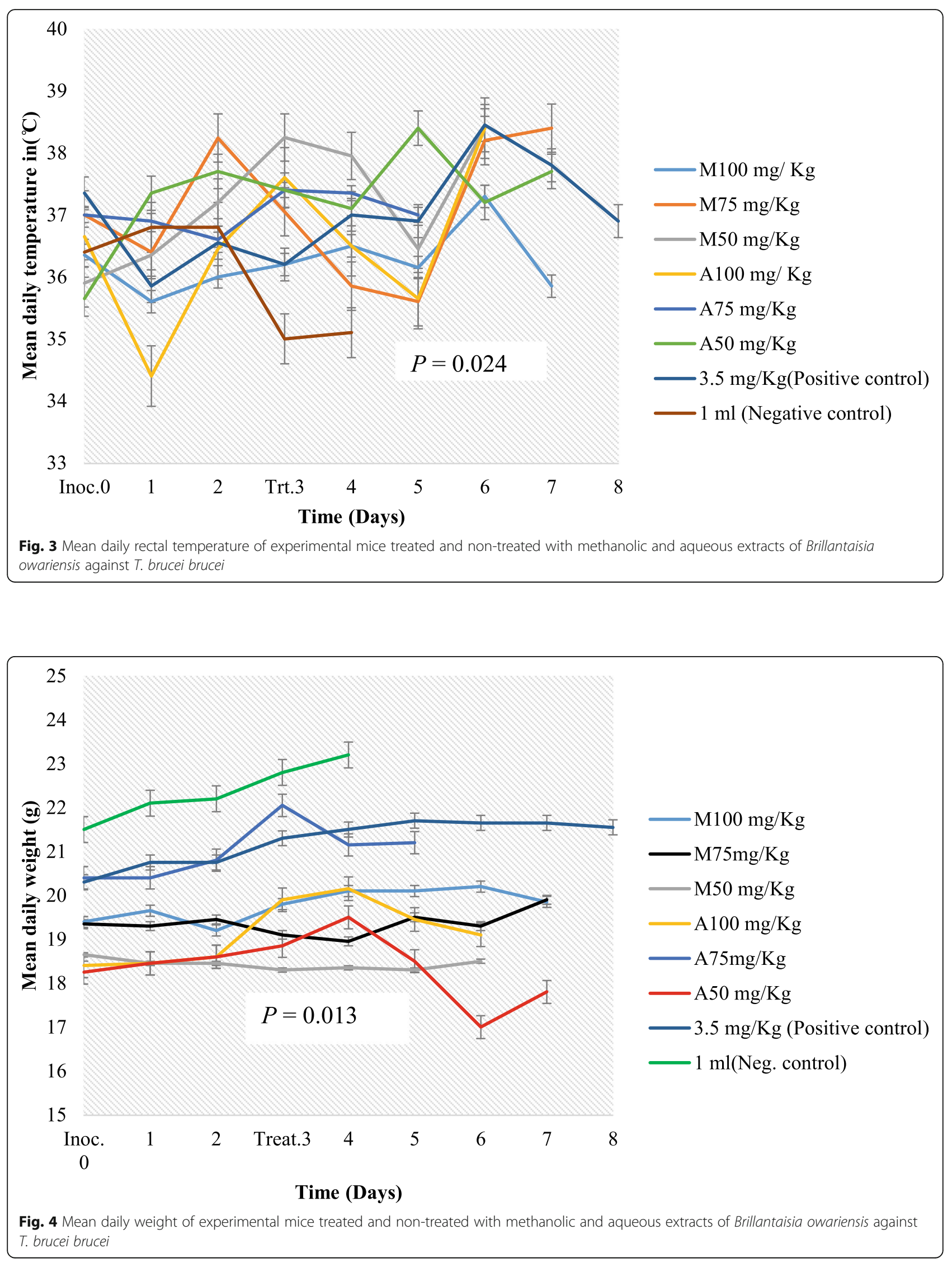

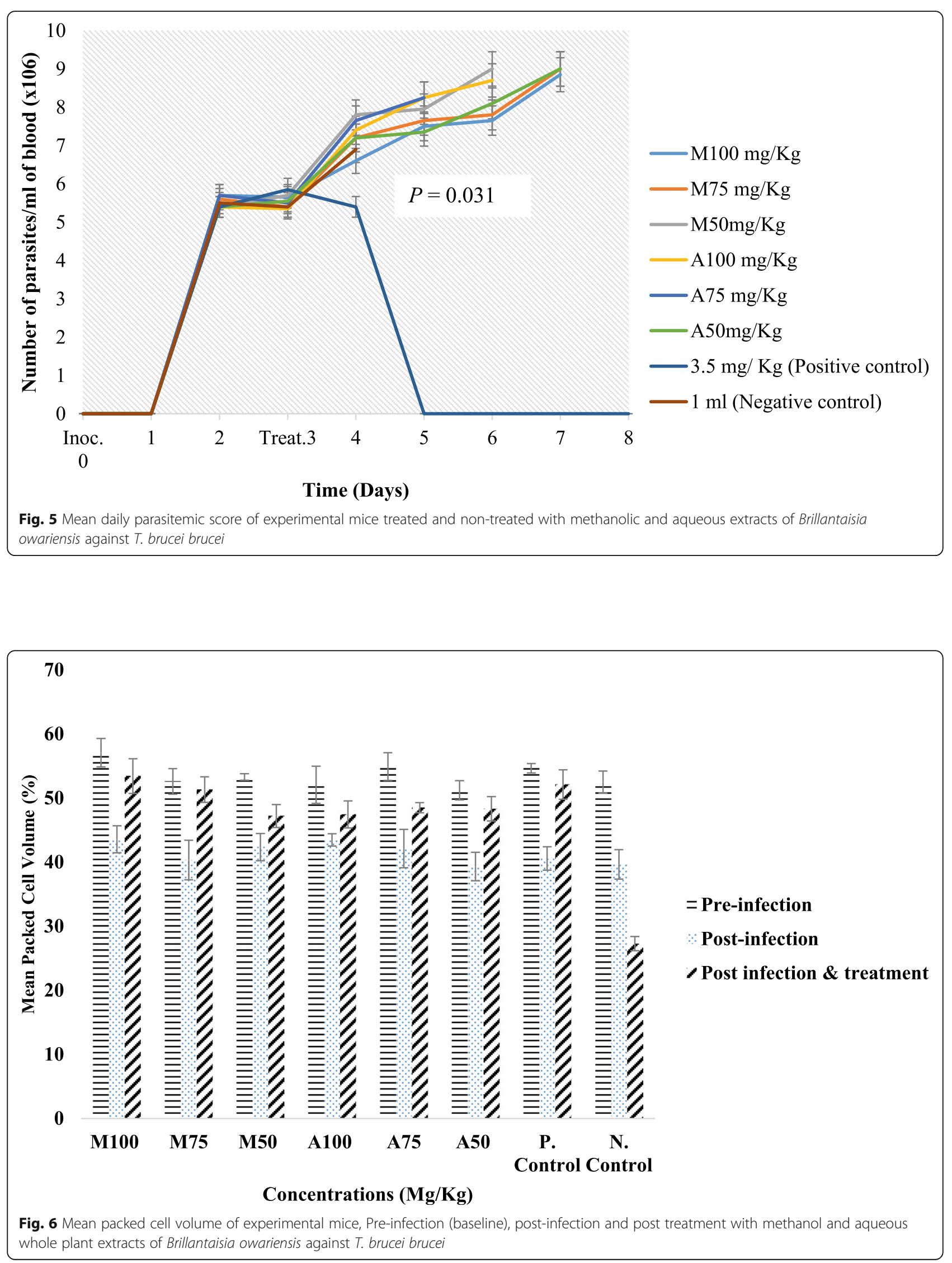


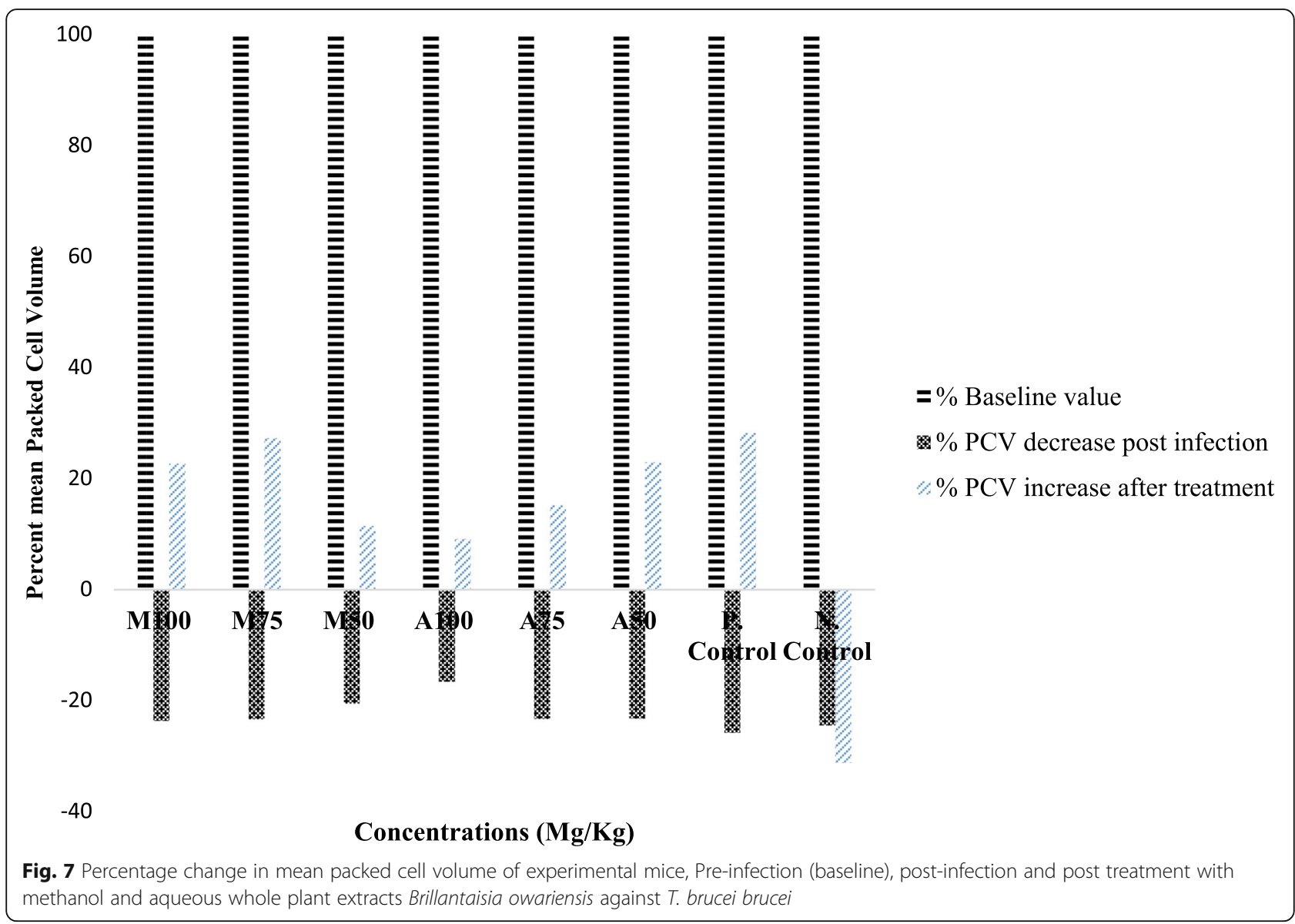

in comparison to the post infection values prior treatment (Fig. 7).

\section{Mean daily survival time}

Animals treated with methanol extract of $100 \mathrm{mg} / \mathrm{kg}, 75$ $\mathrm{mg} / \mathrm{Kg}$ and $50 \mathrm{mg} / \mathrm{Kg}$ aqueous extracts had the highest mean survival time of 8 days as compared to the negative control group (Fig. 8) while animals in the positive control group that received Diminazene aceturate had a mean survival time of 9 days (Fig. 8).

\section{Discussion}

One of the best ways to ascertain the safety of plant extracts is toxicological assessment accompanied by appropriate histological studies. The acute oral toxicity studies $\left(\mathrm{LD}_{50}\right)$ for methanol and aqueous plant extracts in this study were calculated at $3535 \mathrm{mg} / \mathrm{kg} /$ body weight. A scale proposed by Lorke [21] roughly classifies substances that posess $\mathrm{LD}_{50}<1.0 \mathrm{mg} / \mathrm{Kg}$ as very toxic; those with $\mathrm{LD}_{50}$ up to $10 \mathrm{mg} / \mathrm{kg}$ as toxic, $\mathrm{LD}_{50}$ up to $100 \mathrm{mg} /$ $\mathrm{kg}$ as less toxic and slightly toxic when $\mathrm{LD}_{50}$ up to 1000 $\mathrm{mg} / \mathrm{kg}$. Substances with $\mathrm{LD}_{50}$ values more than 5000 $\mathrm{mg} / \mathrm{Kg}$ are non-toxic. This therefore suggest that the extract of Brillantaisia owariensis is non-toxic. Similarly, the acute toxicity study of the stem-bark methanol extract of Khaya senegalensis had an $\mathrm{LD}_{50}$ of $3807 \mathrm{mg} /$ $\mathrm{Kg} / \mathrm{body}$ weigh in rats and declared as non-toxic [28]. The Liver and kidney are important organs that play a vital role in bio-transformation and elimination of many toxic together with their metabolites from the body, and are the primary target organs of toxic injury because of its role $[29,30]$. In this study it was observed that oral administration of the extract caused some mild to moderate histological effects mostly in the liver and kidney indicating that it mildly hepatotoxic and nephrotoxic. Lymphocytic cell infiltration observed may be due to presence of the flavonoid glycoside present in B. owariensis, the presence of flavonoid glycosides has been suggested to cause focal inflammation around the portal triad on the liver with no effect on the kidney [31]. Presence of saponin in plant extract has been reported to cause histopathological alterations in rats [32].

There was no significant increase in the mean daily rectal temperature of all extract-treated animals. A characteristic sign and symptom of trypanosomosis in susceptible animals is the increase in body temperature [33, 34]. Despite undulating parasitaemia observed in mice treated with methanol extract and progressive 


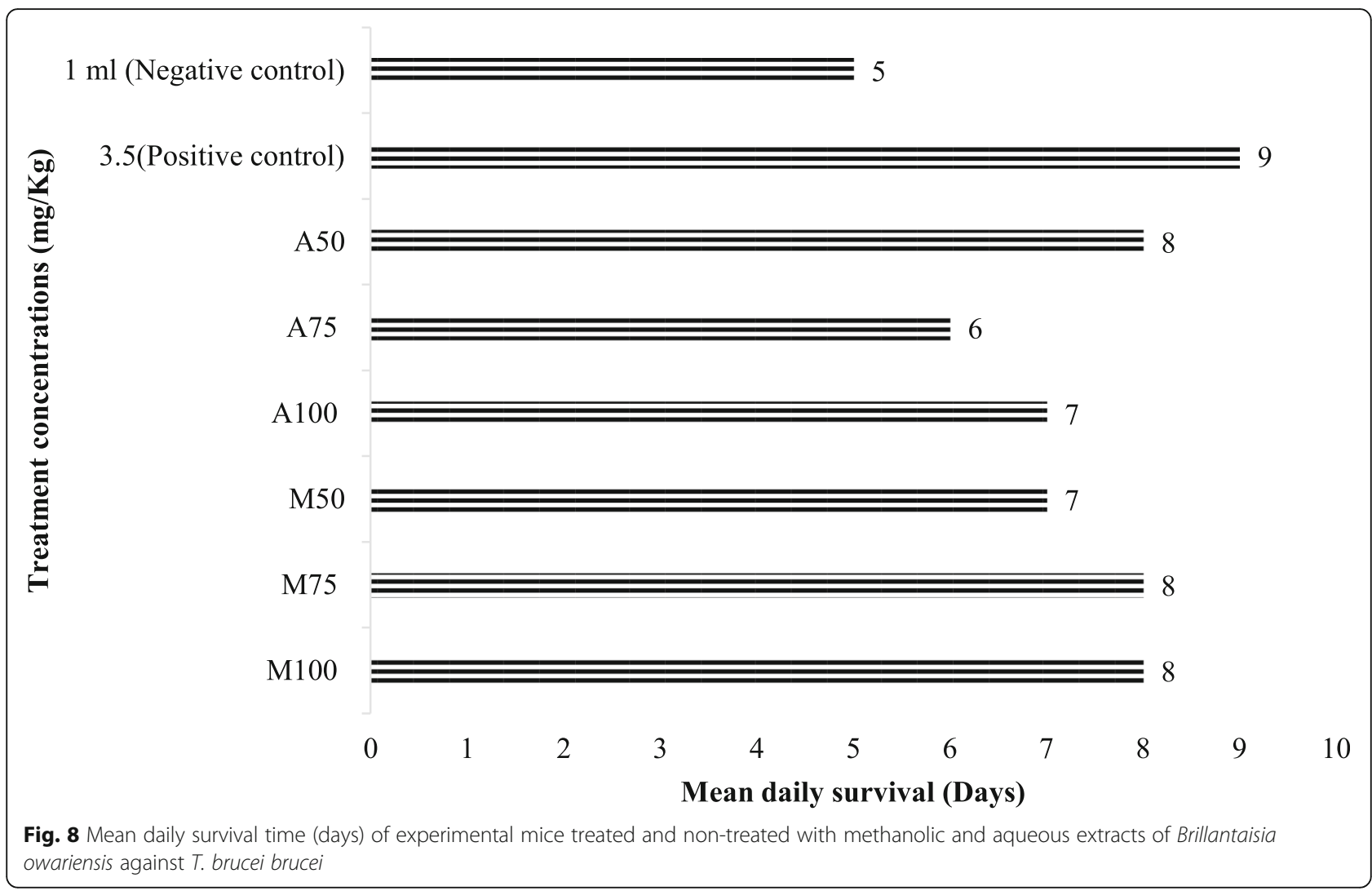

parasitaemia observed when treated with aqueous extract, there was no conforming undulating pyrexia. This could be due to the presence of the compound Acetamide, N-(4-hydroxyphenyl)-N-methyl (Paracetamol) which is an antipyretic, which may have be responsible for insignificant increase in mean rectal temperature of the test organisms. Anosa [35] observed that increase in parasitaemia and pyrexia did not simultaneously occur. The result from this study is in discordance with the reports of Mbaya et al. [36, 37] that a direct relationship exists between undulating pyrexia and fluctuating parasitaemia in trypanosomosis.

Although weight loss has been observed as one of the primary clinical signs of African trypanosomosis [38], the lack of significant loss of weight in mice employed for this study may be related to the high sources of nutrients in B. owariensis [39]. Furthermore, an important factor for the attained weight gain in mice in this study could be associated with increased supply of oxygen and nutrients due to the improved PCV level [40]. In contrast to this study, Ngure et al. [41] reported that all trypanosome-infected mice treated with Azadiracta indica bark extract showed a significant decline in body weight during the experimental period except those treated with Melasorpol (Mel-B).

The in-vivo antitrypanosomal activity of the extracts revealed that there was no cessation or complete elimination of parasites from the bloodstream of infected mice when administered aqueous and methanol extract of $B$. owariensis, but only reduced the level of parasitaemia. Several researchers made similar observations on reduction in parasitaemia when different plant extracts were administered to laboratory animals [42-44]. It is very likely that the oral route of administration of the plant extract in this study could course the failure of the extract to clear the parasite from the blood because the active compounds in the extracts may have failed to reach the site of action or rapid metabolization $[45,46]$. It is also possible that the secondary metabolites in the extracts underwent biotransformation within the gastrointestinal tract and liver, thereby preventing completely elimination of the parasites. It is also likely that the nonefficacy of the plant could be the trypanosome species employed in this study or the animal model used [47]. It has been reported that BALB/c mice show lesser survival and less parasite control when compared to $\mathrm{C} 57 \mathrm{Bl} / 6$ mice [48], and that $\mathrm{BALB} / \mathrm{c}$ mice exhibit prolonged survival in T.B. gambiense infection, in contrast to T. $b$. rhodesiense and T. b. brucei infections [49].

The reduction of PCV values by more than $20 \%$ of the baseline values in all mice day 3 post-infection is an indication of haemolytic anaemia, and is considered the most characteristic symptom whose severity is linked to the level of parasitaemia [50]. Interestingly, following 
treatment with aqueous and methanol extracts of $B$. owariensis, there was significant restoration of the haemolytic condition and increase in the survival time in all the treated groups over the negative (non-treated) control group, and this could be attributed to the presence of secondary metabolites such as alkaloids with have been reported to reverse haemolysis [51, 52]. Additionally, it has been reported that B. owariensis is rich in amino acids which are building blocks of protein with a high quantity of Glycine which is needed during periods of rapid growth and for the biosynthesis of porphyrins of haemoglobin [39]. Similarly, Brillantasia nitens is reported to have haematinic activity [53]. Furthermore, the haematic activity of B. owariensis observed in this study, thus lend credence to it use in folklore medicine in the management of anaemia South Western Nigeria, and other African countries especially in Democratic republic of Congo [19].

Generally, the infected mice that were treated with methanol extract had the highest mean survival time of 8 days compared to the mice treated with aqueous extracts and the non-treated negative control. This could be attributed to high presence of alkaloids, saponins, cardiac glycoside, and anthraquinone in the methanolic extract with higher antitrypanosomal activities $[54,55]$.

\section{Conclusion}

The extracts of $B$. owariensis are relatively non-toxic with a good safety margin when administered to mice orally. Crude methanol extract exhibited a better suppressive and haematinic antitrypanosomal activities than the aqueous extract, and it has a promising effect by its ability to reduce anaemia in mice challenged with $T$. brucei brucei, and prolonged survival.

\section{Abbreviations}

AAT: Animal African Trypanosomosis; HAT: Human African Trypanosomiasis: T. b. brucei: Trypanosoma brucei brucei; PCV: Packed Cell Volume; H\&E: Haematoxylin and Eosin; LD 50 : Median Lethal Dose

\section{Acknowledgements}

The authors appreciate the efforts of the University Management and head of Department of Zoology, Ahmadu Bello University and Head of for providing the facilities used for this Research.

\section{Authors' contributions \\ NGA, SBR-Y, YAW, SJO and DMS conceptualized and designed the study. NGA carried out the experiment, collected data and drafted the manuscript. SBR-Y, YAW, SJO and DMS supervised the experiment in the laboratory and revised the manuscript. YAW, SJ analyzed the data and interpreted the results. All authors have read and approved the final version of the manuscript.}

\section{Funding}

This research did not receive any specific grant from funding agencies in the public, commercial, or not-for-profit sectors. The research was solely funded by the authors.

\section{Availability of data and materials}

The datasets used and/or analyzed during the current study are available on reasonable request.

\section{Declarations}

\section{Ethics approval}

The approval for the use of animals was obtained from the Ethical Committee on Animal Use and Care, A.B.U., Zaria, Nigeria. (Approval Number: ABUCAUC/2018/062). All applicable international, national, and/or institutional guidelines for the care and use of animals were adequately followed.

\section{Consent for publication \\ Not applicable.}

\section{Competing interests}

The authors declare that they have no competing interests.

\section{Author details}

'Department of Zoology, Faculty of Life Sciences, Ahmadu Bello University, Zaria, Kaduna, Nigeria. ${ }^{2}$ National Universities Commission, Maitama, Abuja, Nigeria.

Received: 14 January 2021 Accepted: 1 April 2021

Published online: 13 April 2021

\section{References}

1. D'Archivio S, Medina M, Cosson A, Chamond N, Rotureau B, Minoprio P, et al. Genetic engineering of Trypanosoma (Dutonella) vivax and in vitro differentiation under axenic conditions. PLoS Negl Trop Dis. 2011;5(12): e1461. https://doi.org/10.1371/journal.pntd.0001461.

2. Cayla M, Rojas F, Silvester E, Venter F, Mathews KR. African trypanosomes. Parasit. Vectors. 2019;12:190. https://doi.org/10.1186/s13071-019-3355-5.

3. WHO. interim guidelines for the treatment of gambiense human African trypanosomiasis. Geneva: World Health Organization; 2019. Licence: CC BY-NC-SA 3.0 IGO. Available from: https://www.ncbi.nIm. nih.gov/books/NBK545514/

4. Anita RE, Olayemi JO, Aina OO, Ajaiyeoba EO. In vitro and in vivo animal model antitrypanosomal evaluation of ten medicinal plant extracts from southwest Nigeria. Afr J Biotechnol. 2009;8(7):1437-40.

5. Bizimana $N$, Tiejen U, Zessin $K H$, Diallo D, Djibril D, Melzig MF, et al. Evaluation of medicinal plants from Mali for their in-vitro and in-vivo trypanocidal activity. J Ethnopharmacol. 2006;103:350-6.

6. Holmes P. Tsetse-transmitted trypanosomes - their biology, disease impact and control. J. Invertebr Pathol. 2013;112 Suppl:S11-4.

7. Swallow BM. Impacts of Trypanosomiasis on African Agriculture. In: PAAT Technical and Scientific Series No. 2. Rome, Italy: Food and Agriculture Organisation of the United Nations (FAO); 2000.

8. Toya NB. Immunobiology of African trypanosomes: Need of alternative interventions. J Biomed Biotechnol. 2010;2010:389153. https://doi.org/10.11 55/2010/389153.

9. Barrett MP, Vincent IM, Burchmore RJ, Kazibwe AJ, Matovu E. Drug resistance in human African trypanosomiasis. Future Microbiol. 2011;6(9): 1037-47.

10. Wurochekke AU, Anyanwu GO. Antitrypanosomal activity of anogeissus leiocarpus in rats infected with Trypanosoma brucei brucei. Int Res J Biotechnol. 2012;3(1):5-9.

11. Abdulazeez AM, Baba IA, Yenusa EZ, Omanibe SJ, Oladimeji IH. Anti trypanosomal effect of Peristrophe bicalyculata extracton Trypanosoma brucei brucei-infected rats. Asian Pac J Trop Med. 2013;37:523-31.

12. Abedo J, Jonah $\mathrm{O}$, Abdullahi R, Mazadu M, Idris $\mathrm{H}$, Muhammed $\mathrm{H}$, et al. Evaluation of anti-trypanosomal activity of Tapinanthus globiferus and Gongronema latifolium on Trypanosoma congolense. Biosci Res. 2013;101:20-8

13. Igbo UE, Igoli JO, Onyiriuka SO, Ejele AE, Ogukwe CE, Ayuk AA, et al. Antitrypanosomal and Antioxidant Activities of Moringa oleifera Lam Leaf Extracts. JPCBS. 2015;3(1):17-23.

14. Dyary HO, Arifah AK, Sharma RS, Rasedee A, Mohd-Aspollah MS, Zakaria ZA. Antitrypanosomal screening and cytotoxic effects of selected medicinal plants. Trop Biomed. 2014;31(1):89-96. 
15. Bargash SM. Evaluation of Invitro and Invivo activities of some medicinal plant extracts against trypanosomaisis. Int J Adv Res. 2016;4(8):1168-78.

16. Tauheed AM, Suleiman MM, Mamman M, Lawal IA. Exvivo trypanostatic effect of stem-bark extracts of Securidaca longipedunculata (Fres. Holl) against Trypanosoma brucei brucei. Afr J Biotechnol. 2016;15(51):2789-94.

17. Okoh ME, Obadiah H, Igwe EE. Invivo Anti Trypanosomal Activity of Aqueous Extract of Azadirachta indica Leaves on Trypanosoma brucei brucei Infected Mice. IJIDT. 2018;3(1):13-7.

18. Beentje HJ. Brillantaisia owariensis. The IUCN Red List of Threatened Species 2017:e.T185444A84260589. https://doi.org/10.2305/IUCN.UK.20171.RLTS.T1 8544A84260589.en.

19. Ngbolua KN, Benamambote BM, Mpiana PT, Muanda DM, Ekutsu E, Tshibangu DST, et al. Ethno- botanical survey and Ecological study of some Medicinal plants species traditionally used in the District of Bas-Fleuve (Bas- Congo Province, Democratic republic of Congo). Res J Chem. 2013;1(2):1-10.

20. Jigna P, Chanda S. In-vitro antimicrobial activities of extracts of Launaea Procumbeus Roxb. (labiateae). Vitis viniferaal L. (vitaceae) and Cyperus votondus L. (cypevaceae). Afr J Biomed Res. 2006;9:89-93.

21. Lorke D. A new approach to practical acute toxicity testing. Arch Toxicol. 1983;54:275-87.

22. Meyer CW, Ootsuka $Y$, Romanovsky AA. Body temperature measurements for metabolic phenotyping in mice. Front Physiol. 2017;8(520):1-13.

23. Aremu A, Kingsley El, Talha BK, Akeem AO, Ibrahim RA, Jimoh AG, et al. Methanolic leaf extract of Moringa oleifera improves the survivability rate, weight gain and histopathological changes of Wister rats infected with Trypanosoma brucei. Int J Vet Sci Med. 2018;6:39-44.

24. Herbert WJ, Lumsden WHR. Trypanosoma brucei: A rapid "matching" method for estimating the host's parasitemia. Exp Parasitol. 1976;40:427-31.

25. Aremu A, Eghianruwa Kl, Biobaku KT, Ahmed AO, Basiru A. Crude methanolic extract of Moringa oleifera leaves improves the efficacy of Diminazene Aceturate in the treatment of Trypanosome infected rats. Ceylon J Sci. 2017;46(4):43-53.

26. Ochei J, Kolhatkhar A. Medical laboratory science, theory and practice. Tata Mac Graw-hill. 2000;2000:283.

27. Microsoft Excel Chart Wizard. Microsoft Coporation. 2013.

28. Suleiman MM, Tauheed M, Babandi JS, Umar R, Sulaiman MH, Shittu M, et al. An invivo experimental trial to determine the efficacy of stem-bark extract of Khaya senegalensis A. Juss (Meliaceae) for treating gastric ulcer in rat. J Appl Res Med Aromat Plants. 2013;(3):352-61.

29. Versteiln AM, Di MF, Leemreis JR, Groeneveld AB, Musters RJ, Sipkema P. Molecular mechanisms of acute renal failure following ischemia/reperfusion. Int J Artif Organs. 2004;27:1019-29.

30. van de Water B, de Graauw M, Le Dévédec S, Alderliesten M. Cellular stress responses and molecular mechanism of nephrotoxicity. Toxicol Lett. 2006; 162:83-93.

31. Ezejiofor AN, Orish CN, Orish EO. Effect of aqueous leaves extract of Costus afer Ker Gawl (Zingiberaceae) on the liver and kidney of male albino wistar rat. Ancient Sci Life. 2013;33:4-9.

32. Cherian KM, Gandhi VM, Mulky M. Toxicological evaluation of Mowrah (Madhuca latifolia) seed material. Indian J Exp Biol. 1996;34(1):61-5.

33. Uza DV, Umunna NN, Bawa EK. The effects of trypanosomiasis and other factors on rectal temperature and blood picture of muturu cattle (Bos brachceros) reared under traditional village management system. Bull Anim Health Prod Afr. 1998;46:125-31.

34. Wada YA, Onive SJ, Rekwot PI, Okubanjo OO. Single and mixed interaction of experimental Trypanosoma brucei brucei and Trypanosoma evansi on the semen collection reaction time and spermatozoa morphology of Yankasa rams. JAVAR. 2017;3(4):360-7 Available from: https://www.banglajol.info/ index.php/JAVAR/article/view/31517. [cited 9Mar.2021].

35. Anosa VO. Studies on the parasitaemia, plasma volume, leukocyte and bone marrow cell counts and the moribund state in Trypanosoma brucei infection of splenectomised and intact mice. Zentralbl Veterinarmed. 1980;27:169-80.

36. Mbaya AW, Aliyu MM, Nwosu CO, Taiwo VO, Ibrahim UI. Effects of melarsamine hydrochloride (Cymelarsan ${ }^{\oplus}$ ) and diaminazene aceturate (Berenil ${ }^{\oplus}$ ) on the pathology of experimental Trypanosoma brucei infection in red fronted gazelles (Gazella rufifrons). Vet Parasitol. 2009;163(1-2):140-3.

37. Mbaya AW, Kumshe HA, Ogwiji M, Naanman PJ. The effect of Dimethylsulphoxide on the topical application of Diminazene aceturate (Berenil ${ }^{\oplus}$ ) in an experimental Trypanosoma brucei infection in albino Rats. Nig Vet J. 2013;34(2):749-59.
38. Spickler AR. (2018). African Animal Trypanosomiasis. 2018. Retrieved from http://www.cfsp.iastate.edu/Diseaselnfo/factsheets.php.

39. Akuru UB, Amadi BA. Phytochemicals and antioxidant properties of some selected medicinal plants. J Pharmacogn Phytochem. 2018;7(5):283-5.

40. Tadesse B, Terefe G, Kebede N, Shibeshi W. In-vivo antitrypanosomal activity of dichloromethane and methanol crude leaf extracts of Dovyalis abyssinica (Salicaceae) against T. congolense. BMC Compl Alternative Med. 2015;15:278.

41. Ngure RM, Ongeri B, Karori SM, Wachira W, Maathai RG, Kibugi JK, et al. Antitrypanosomal effects of Azadiracta indica (neem) extract on Trypanosoma brucei rhodesiense- infected mice. East J Med. 2009;14:2-9.

42. Ibrahim H, Ogbadoyi E, Adamu K, Bello M, Yemisi I. Evaluation of antitrypanosomal activity of ethyl acetate extract of Adansonia digitata seed extract in T. b. brucei infected albino mice. Int J Drug Res Tech. 2012;2:454-60.

43. Mergia E, Shibeshi W, Terefe G, Teklehaymanot T. Phytochemical screening and in-vitro antitrypanosomal activity of aqueous and methanol leaf extract of Verbascum sinaiticum (Scrophulariaceae) against Trypanosoma congolense field isolate. J Clin Exp Pathol. 4:183. https:// doi.org/10.4172/2161-0681.1000183.

44. Tauheed AM, Suleiman MM, Mamman M, Lawal IA. Invivo antitrypanosomal effects of stem-bark extracts of Securidaca longipedunculata in rats experimentally infected with Trypanosoma brucei brucei. Sokoto J Vet Sci. 2017:15(3):78-84.

45. Dwivedi SK. Evaluation of indigenous herbs as antitrypanosomal agents. In: Mathias E, Rangnekar DV, McCorkle C.M. 1999. Ethnoveterinary Medicine: Alternatives for Livestock Development. Proceedings of an International Conference held in Pune, India, on November 4-6, 1997.1999:Volume1: Selected Papers. BAIF Development Research Foundation, Pune, India.

46. Wurochekke AU, James DB, Bello MI, Ahmodu A. Trypanocidal activity of the leaf of Guira senegalensis against Trypanosoma brucei brucei infection in Rats. J Med Sci. 2005;5:1-4.

47. Mohammed Al, Aminu M, Murtala Bl, Abubakar B. Antitrypanosomal activity of African medicinal plants: A review update. J Ethnopharmacol. 2014;154:26-54.

48. de Menezes VT, Queiroz AO, Gomes MA, Marques MA, Jansen AM. Trypanosoma evansi in inbred and Swiss Webster mice: distinct aspects of pathogenesis. Parasitol Res. 2004;94:193-200.

49. Inoue N, Inoue M, Kuriki K, Yamaguchi H, Nagasawa H. Interleukin 4 is a crucial cytokine in controlling Trypanosoma brucei gambiense infection in Mice. Vet Parasitol. 1999;86:173-84.

50. Silva TM, Olinda RG, Rodrigues CM, Camara AC, Lopes FC, Coelho WA, et al. Pathogenesis of reproductive failure induced by Trypanosoma vivax in experimentally infected pregnant ewes. Vet Res. 2013;44(1). https://doi.org/1 0.1186/1297-9716-44-1.

51. Mbaya A, Kumshe $H$, Nwosu CO. The mechanism of anaemia in trypanosomiasis: a review. In: Silverberg S, editor. Anemia. Croatia: InTech; 2012. p. 269-82.

52. Lakshmi KS, Sangeetha D, Sivamani S, Tailarasan M, Rajesh TP, Anandraj B. Invitro antibacterial, antioxidant, haemolytic, thrombocytic activities and phytochemical analysis of Simarouba gluaca leaves extracts. Int J Pharm Sci Res. 2014;5(2):432-7.

53. Akah PA, Okolo CE, Ezike AC. The haematinic activity of the methanol leaf extract of Brillantasia nitens Lindau (Acanthaceae) in rats. Afr J Biotechnol. 2009;8(10):2389-93.

54. Abu AH, Uchendu CN. Invivo trypanocidal activity of hydroethanolic extract of Hymenocardia acida stem bark in rats. Vet World. 2011;43:113-6.

55. Bala AY, Adamu T, Abubakar U, Ladan MJ. Inhibition of Trypanosoma brucei brucei by extracts from Waltheria indica L. sleepy morning. Res J Parasitol. 2011;6:53-9.

\section{Publisher's Note}

Springer Nature remains neutral with regard to jurisdictional claims in published maps and institutional affiliations. 